\title{
Application of a plant bioassay for the evaluation of ecotoxicological risks of heavy metals in sediments affected by mining activities
}

\author{
Mari Luz García-Lorenzo \& María J osé Martínez-Sánchez \& \\ Carmen Pérez-Sirvent
}

\begin{abstract}
Purpose The objective of this work was to evaluate the effectiveness of a plant bioassay (Phytotoxkit ${ }^{\circledR}$ ) for screening ecotoxicological risks in sediments affected by mining activities.

Materials and methods A total of 42 sediment samples affected by mining activities were studied, including 39 sediment samples from the Sierra Minera, Spain, an area affected by old extraction procedures, and three sediments from an area affected by opencast mining. These three samples were then mixed with limestone filler at 10, 20 and $30 \%$, providing nine stabilised samples. The total and soluble metal(loid) content (As, $\mathrm{Cd}, \mathrm{Cu}, \mathrm{Fe}, \mathrm{Pb}$ and $\mathrm{Zn}$ ) was determined in all samples, and the Phytotoxkit ${ }^{\circledR}$ bioassay was applied to determine the ecotoxicological effect of this procedure.

Results and discussion The stabilised material had a neutral $\mathrm{pH}$ and low soluble metal(loid) concentration, similar to that of samples in which a natural attenuation process had taken place because of mixing with surrounding carbonate-rich materials. An ecotoxicological survey identified the low toxicity levels of the stabilised samples.
\end{abstract}

Responsible editor: Klara Hilscherova

Electronic supplementary material The online version of this article (doi:10.1007/s11368-014-0942-0) contains supplementary material, which is available to authorized users.

\section{L. García-Lorenzo}

Department of Petrology and Geochemistry, Faculty of Geology, University Complutense of Madrid, Jose Antonio Novais 2, 28040 Madrid, Spain

e-mail:mglorenzo@geo.ucm.es

M. J. Martínez-Sánchez : C. Pérez-Sirvent( ${ }^{*}$ )

Department of Agricultural Chemistry, Geology and Pedology,

Faculty of Chemistry, University of Murcia, Campus de Espinardo,

30100 Murcia, Spain

e-mail:melita@um.es
Conclusions The applied bioassay is a good tool for screening metal(loid) contamination in areas affected by mining activities, since it provides information on both natural and simulated attenuation processes. The mixing of sediments with limestone filler could be applied to the remediation of zones affected by mining activities, because the toxicological effect on the tested organisms in the stabilised sediments was reduced significantly and the metal(loid) content was diminished.

Keywords Ecotoxicity · Environmental risk · Immobilisation · Limestone filler · Metal(loid)s · Mining activity

\section{Introduction}

Acid mine drainage (AMD) is a serious environmental problem caused by sulphide mining and is responsible for the pollution and degradation of both soils and waters. Acid mine drainage may lead to high concentrations of dissolved metal(loid)s, together with high levels of sulphate and low $\mathrm{pH}$ (Sarmiento et al. 2009; Asta et al. 2010). Sometimes, when surrounding materials are capable of buffering drainage, the metal(loid) content may be attenuated. A primary control on the process is acid neutralisation, that occurs during transport processes when the drainage encounters materials of high buffering capacity. As $\mathrm{pH}$ increases, aqueous metal(loid) species tend to precipitate in the form of hydroxide, oxyhydroxide or hydroxysulphate phases (Berger et al. 2000). Metals may also adsorb to the surfaces of the precipitates formed, removing them from solution (Nordstrom 1982; Chapman et al. 1983). Moreover, dilution can attenuate metal(loid) concentration, independently of any chemical reaction (Berger et al. 2000). 
Over the past few decades, many remediation technologies have been applied throughout the world to deal with contaminated soils and waters. Among such remediation techniques, chemical immobilisation by means of soil amendments has been investigated as an alternative technique for a wide range of contaminated sites (Scanferla et al. 2009). A number of natural or synthetic materials, such as phosphate rocks (Mignardi et al. 2012), zeolites (Kosobucki et al. 2008; Shi et al. 2009), municipal biosolids (Madrid and Florido 2010), red mud (Garau et al. 2007; Liu et al. 2011) and carbonates have been tested in order to evaluate their ability to immobilise toxic metal(loid)s. Limestone filler is a good choice for remediation processes because of its low permeability and low solubility, it has a high degree of physicalchemical stability, it is non-toxic and it has a finely divided calcium carbonate content (Pérez-Sirvent et al. 2007, 2011; Martínez-Sánchez et al. 2008). In addition, the use of this material, which is in fact a residue, is advantageous due to the subsequent revalorisation that results in a reduction of the costs.

In order to demonstrate that remediation techniques are effective, contaminated soils are usually subjected to chemical analysis before and after treatment (Plaza et al. 2005). However, a simple chemical analysis is not sufficient to fully evaluate the toxic effects because the ecotoxicological danger in the environment is not reflected and no information is provided on the effects of the chemical compounds. To estimate the environmental risk of contaminants, chemical methods need to be complemented with biological procedures (Leitgib et al. 2007; García-Lorenzo et al. 2009).

Biotests are example of commonly used biomonitoring tools (Wadhia and Thompson 2007; López-Roldán et al. 2012; Baran and Tarnawski 2013). Plants are important components of ecosystems since they are the primary food producers and so it is important to identify the magnitude of any toxic effects on them. The aim of this study was to evaluate the effectiveness of bioassays as a tool for identifying ecotoxicological risks in sediments affected by mining activities. Considering that the natural attenuation of metal(loid)s could occur when contaminated materials from mining activities are mixed with carbonate host rocks and sediments during transport processes, a simulation of stabilisation/immobilisation processes using limestone filler was applied to several contaminated sediments. The efficiency of this approach was assessed by a phytotoxicity test.

\section{Material and methods}

\subsection{Study area}

The Sierra Minera of Cartagena-La Unión is situated in the south-east of the Iberian Peninsula, Spain, in the province of
Murcia, where it constitutes the south-eastern end of the Betic mountain chains. This area was one of the largest zinc (Zn), iron $(\mathrm{Fe})$ and lead $(\mathrm{Pb})$ ore deposit in the south of Europe (Oen et al. 1975; Ovejero et al. 1976; Gómez-Ros et al. 2013). Iron is present in the forms of oxides, hydroxides, sulphides, sulphates, carbonates and silicates; $\mathrm{Pb}$ and $\mathrm{Zn}$ occur in galena, sphalerite, carbonates, sulphates and $\mathrm{Pb}$ - or $\mathrm{Zn}$-bearing manganese (Mn) and Fe oxides. As a result of massive extraction over centuries, the area contains large amounts of mining wastes (see Electronic Supplementary Material).

The average annual temperature is $17^{\circ} \mathrm{C}$ and precipitation is $<300 \mathrm{~mm}$, with occasional torrential rainfall, which frequently occurs between the end of summer and autumn. Perennial streams do not exist, and surface water consists of ephemeral streams, which are only operational during rainfall events. The flashy streamflows result in significant amounts of sediment being transported during and after rainfall episodes.

The study area has been subjected to intense mining activity since the times of the Roman Empire. Until the nineteenth century, small underground exploitations were predominant and, as a consequence, there are many contamination sources formed by mining steriles, waste piles, tailing dumps and foundry residues (García-Lorenzo et al. 2012). Weathering and transport processes following torrential rainfall led to natural attenuation processes when transported materials were mixed with surrounding materials of a carbonate nature.

As much as one third of the total reserves of the Sierra Minera were extracted between 1957 and 1991, when the Peñarroya Mining and Metallurgical Society extracted ore on a large scale by opencast mining. The ore concentration factory had the capacity to process up to $10,000 \mathrm{t} \mathrm{day}^{-1}$, using a seawater floatation technique. From Lavadero Roberto (one of the biggest flotation plants in the world), the waste materials were discharged directly into the sea-first into the inner part of the bay and later at a considerable distance from the shore (Martínez-Sánchez et al. 2008). These wastes mainly consisted of ore materials (galena, pyrite and sphalerite), phyllosilicates, siderite, Fe oxides and sometimes alteration products such as jarosite, alunite, kaolinite and greenalite. As a result, the whole of the Portman Bay was filled up with wastes.

\subsection{Experimental design and sample collection}

Thirty-nine sediment samples were collected from the area affected by the oldest mining exploitations and at increasing distances from the contamination sources. Three categories were established as a function of distance from the contamination sources (García-Lorenzo et al. 2012): sediments located close to the contamination sources, sediments located along the dispersion routes and sediments minimally affected due to attenuation. 
Sediment samples from the surface soil $(0-25 \mathrm{~cm})$ were collected. Five subplots $(25 \mathrm{~cm} \times 25 \mathrm{~cm})$ for soil sampling were selected at the centre and along the diagonal lines of the plots $(1 \mathrm{~m} \times 1 \mathrm{~m})$. Sediment samples were collected from each subplot with a shovel, mixed and homogenised before taking a subsample $(2 \mathrm{~kg})$. All samples were transported in polyethylene bags and stored at $4{ }^{\circ} \mathrm{C}$ until analysis.

In addition, three sediment samples (S1, S2 and S3) were collected from a zone corresponding to the most recent mining activities. In these samples, the attenuation process was simulated by mixing with limestone filler; $0.5 \mathrm{~m}^{3}$ of sediment samples were mixed with different proportions of limestone filler, $10 \%$ (S4, S5 and S6), $20 \%$ (S7, S8 and S9) and $30 \%$ (S10, S11 and S12). The stabilised samples were stored in containers for a year and moistened three times (60 l each episode) to simulate rainfall episodes. After this, samples were collected and analysed.

\subsection{Chemical analysis}

All sediment samples were air-dried and sieved through a 2-mm screen. The $\mathrm{pH}$ was determined in a 1:5 ( $w / v)$ suspension of sediment in pure water. Electrical conductivity (EC) was measured in the extracts obtained by filtering the 1:5 suspensions through a $0.45-\mu \mathrm{m}$ cellulose acetate disc filter. High-quality water, obtained by means of a Milli-Q water purification system, was used exclusively.

To determine the total metal(loid) content, sediments were ground to a fine powder using a zirconium ball mill. Aliquots $(0.1 \mathrm{~g})$ of sediment samples were placed in Teflon vessels, and a mixture of $5 \mathrm{ml}$ concentrated $\mathrm{HF}, 200 \mu \mathrm{l}$ concentrated $\mathrm{HNO}_{3}$ and $5 \mathrm{ml}$ water was added. After digestion in a conventional microwave oven, the solutions were transferred to a volumetric flask and brought to $50 \mathrm{ml}$. The water-soluble content was determined using a standard leaching test (UNE-EN 12457-1). This fraction reflects the behaviour of the most mobile fraction of pollutants and is strongly related to the high risk of dispersion, solubilisation and bioavailability of contaminants in the environment.

The $\mathrm{Zn}$ and $\mathrm{Fe}$ content was determined by flame atomic absorption spectrometry. The $\mathrm{Pb}$, cadmium (Cd) and copper $(\mathrm{Cu})$ content was determined by electrothermal atomization atomic absorption spectrometry. The measurements were carried using a PerkinElmer model 800 spectrometer (PerkinElmer, Shelton, USA). The arsenic (As) content was measured by atomic fluorescence spectrometry using an automated continuous flow hydride generation spectrometer (PS Analytical, Orpington, UK). The reliability of the results was verified by analysing standard reference materials.

$\mathrm{X}$-ray diffraction (XRD) was used to characterise the mineralogical composition, using $\mathrm{Cu}-\mathrm{K} \alpha$ radiation with a model PW3040 diffractometer (Philips PANalytical, Almelo, The Netherlands). Xpowder software was used to analyse the
X-ray diffraction diagrams obtained by the crystalline powder method. The Powder Diffraction File (PDF2) database was used for peak identification (Martin 2004).

\subsection{Phytotoxicity test}

The phytotoxicity of the sediment samples was evaluated using the Phytotoxkit microbiotest (MicroBioTests Inc., Belgium) previously used by several authors (e.g. BagurGonzález et al. 2011; Bakopoulou et al. 2011; CzerniawskaKusza and Kusza 2011; Oleszczuk et al. 2012; Baran and Tarnawski 2013; Kopec et al. 2013). The Phytotoxkit ${ }^{\circledR}$ test measures the decrease or absence of germination in seeds of selected higher plants exposed for 3 days to a contaminated matrix (compared with controls germinated in a reference soil) and the growth of young roots. It is recommended (OECD 1984) that at least one monocotyledonous and one dicotyledonous species should be used in these tests. The plants selected for the Phytotoxkit microbiotest were as follows: the monocotyl Sorghum saccharatum (Sorgho) and the dicotyls Lepidium sativum (garden cress) and Sinapis alba (mustard). The tests were performed essentially as described in the Phytotoxkit protocol (Phytotoxkit 2004). Ten seeds of each plant were placed at equal distance near the middle ridge of the tests plate on a black filter paper placed on reference soil (control) or sediment samples and hydrated with deionised water. The plates were placed vertically in a holder and incubated for 3 days at $25^{\circ} \mathrm{C}$, in darkness. Pictures of the test plates at the end of the exposure period were taken by a digital camera, and the length of the root of each plantlet was measured using the Image Tool 3.0 software (UTHSCSA, USA).

The percent inhibition of seed germination (IG) and inhibition of root growth (IR) for the plant were calculated using

$$
A-B
$$

IG or IR $1 / 4 \frac{A}{A} \times 100 \%$

where $A$ is the mean seed germination or root length in the control $(\mathrm{mm})$ and $B$ is the mean seed germination or root length in the test sediment (mm). For comprehensive interpretation of the data, seed germination and root elongation were combined in a germination index (GI):

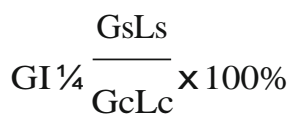

where Gs and Ls are the seed germination (percent) and root elongation (mm) for the sample and Gc, respectively, and Lc is the corresponding control values. Germination index values within the range of $90-110 \%$ were classified as "no effect/ non-toxic". Germination index values $<90 \%$ were classified as inhibition, fand GI values $>110 \%$ were classified as stimulation (Czerniawska-Kusza and Kusza 2011; Baran and Tarnawski 2013). 
Table 1 Analytical parameters of sediment samples from Sierra Minera

\begin{tabular}{|c|c|c|c|c|c|c|c|c|c|c|c|c|c|c|}
\hline & \multirow[t]{2}{*}{$\mathrm{pH}$} & \multicolumn{7}{|c|}{ Total metal(loid) concentration in sediments } & \multicolumn{6}{|c|}{ Metal(loid) concentration in 1:2 water-sediment extract } \\
\hline & & $\mathrm{CE}$ & As (mg kg $\left.{ }^{-1}\right)$ & $\mathrm{Pb}\left(\mathrm{mg} \mathrm{kg}{ }^{-1}\right)$ & $\mathrm{Cd}\left(\mathrm{mg} \mathrm{kg}^{-1}\right)$ & $\mathrm{Cu}\left(\mathrm{mg} \mathrm{kg}{ }^{-1}\right)$ & $\mathrm{Fe}(\%)$ & $\mathrm{Zn}\left(\mathrm{mg} \mathrm{kg}^{-1}\right)$ & As $\left(\mu g \mathrm{l}^{-1}\right)$ & $\mathrm{Pb}\left(\mathrm{mg} \mathrm{l}^{-1}\right)$ & $\mathrm{Cd}\left(\mathrm{mg} \mathrm{l}^{-1}\right)$ & $\mathrm{Cu}\left(\mathrm{mg} \mathrm{l}^{-1}\right)$ & $\mathrm{Fe}\left(\mathrm{mg} \mathrm{l}^{-1}\right)$ & $\mathrm{Zn}\left(\mathrm{mg} \mathrm{l}^{-1}\right)$ \\
\hline \multicolumn{15}{|c|}{ Contamination sources } \\
\hline B1 & 5.0 & 7.4 & 752 & 3,989 & 87.9 & 142 & 25.15 & 8,984 & 51.9 & 5.9 & 12.2 & 2.3 & 5.4 & $3,574.9$ \\
\hline B7 & 3.3 & 2.8 & 3,466 & 26,847 & 44.3 & 999 & 17.04 & 8,867 & 24.0 & 6.3 & 1.6 & 1.8 & 2.0 & $1,722.1$ \\
\hline B8 & 3.2 & 0.6 & 3,211 & 33,804 & 38.9 & 434 & 17.36 & 9,971 & 22.9 & 9.9 & 1.3 & 1.7 & 2.8 & 181.3 \\
\hline B11 & 5.2 & 4.2 & 1,528 & 31,885 & 32.3 & 379 & 35.86 & 11,553 & 26.9 & 2.0 & 2.3 & 1.2 & 1.3 & 26.4 \\
\hline B12 & 5.5 & 1.0 & 1,231 & 18,668 & 40.4 & 652 & 36.13 & 10,595 & 22.8 & $19.9 \times 10^{-3}$ & $20.0 \times 10^{-3}$ & 1.2 & $<\mathrm{dl}$ & 47.5 \\
\hline C1 & 7.4 & 1.8 & 3,421 & 2,456 & 53.1 & 620 & 16.25 & 19,942 & 28.0 & 1.0 & $19.7 \times 10^{-3}$ & $<\mathrm{dl}$ & $<\mathrm{dl}$ & 1.5 \\
\hline $\mathrm{C} 2$ & 7.7 & 2.6 & 1,020 & 3,901 & 53.5 & 826 & 12.06 & 13,376 & 2.2 & 0.6 & $10.8 \times 10^{-3}$ & $59.3 \times 10^{-3}$ & 1.1 & 261.9 \\
\hline C3 & 4.5 & 7.3 & 458 & 3,033 & 59.5 & 225 & 12.83 & 25,273 & 2.3 & 4.3 & 24.2 & 1.1 & 4.4 & $9,932.2$ \\
\hline $\mathrm{C} 4$ & 3.3 & 4.0 & 440 & 2,338 & 54.0 & 250 & 10.66 & 24,067 & 2.7 & 12.7 & 23.7 & 6.2 & 5.2 & $4,261.4$ \\
\hline C5 & 5.1 & 3.4 & 816 & 3,750 & 43.4 & 928 & 8.44 & 9,241 & 3.2 & 4.1 & 10.4 & 0.2 & 5.1 & 973.9 \\
\hline C6 & 6.5 & 1.7 & 438 & 2,891 & 23.2 & 289 & 4.57 & 6,849 & 99.5 & 43.1 & 1.7 & 0.7 & 63.6 & 110.2 \\
\hline C7 & 3.6 & 2.8 & 407 & 2,292 & 41.4 & 147 & 7.28 & 10,397 & 21.0 & 9.9 & 9.1 & 5.3 & 1.6 & $1,317.4$ \\
\hline D2 & 2.5 & 2.5 & 3,939 & 47,619 & 37.5 & 636 & 21.48 & 2,232 & 76.6 & 6.6 & $30.0 \times 10^{-3}$ & 10.5 & 15.7 & 29.9 \\
\hline D3 & 2.1 & 6.2 & 3,210 & 12,148 & 39.0 & 569 & 24.30 & 2,430 & 71.6 & 135.1 & 7.2 & 88.1 & $1,010.3$ & 817.7 \\
\hline D4 & 2.1 & 6.2 & 3,961 & 3,558 & 21.7 & 615 & 19.95 & 2,164 & 60.9 & 1.2 & 6.2 & 65.9 & 26.9 & 585.9 \\
\hline D5 & 2.2 & 6.9 & 2,362 & 3,086 & 23.5 & 345 & 21.85 & 1,722 & 59.0 & 77.8 & 6.1 & 115.5 & $2,529.2$ & 826.8 \\
\hline D6 & 2.2 & 1.6 & 4,429 & 21,884 & 21.7 & 310 & 23.34 & 12,364 & 41.3 & 0.2 & $12.1 \times 10^{-3}$ & 3.8 & 129.5 & 10.0 \\
\hline D7 & 5.8 & 1.3 & 1,609 & 3,486 & 21.1 & 233 & 22.18 & 19,366 & 12.7 & 2.6 & 1.2 & 0.3 & 0.7 & 31.2 \\
\hline D8 & 4.1 & 1.8 & 1,447 & 3,571 & 22.4 & 165 & 18.41 & 9,158 & 38.1 & 12.4 & 2.7 & 3.9 & 1.4 & 307.0 \\
\hline D9 & 4.5 & 6.0 & 1,493 & 3,428 & 54.6 & 207 & 21.38 & 10,169 & 27.5 & 1.9 & 7.6 & 0.4 & 1.6 & $1,039.2$ \\
\hline D10 & 4.5 & 4.7 & 1,260 & 3,438 & 74.6 & 149 & 22.74 & 4,975 & 30.0 & 11.1 & 6.8 & 6.4 & 8.1 & 283.2 \\
\hline D11 & 3.6 & 3.5 & 1,481 & 2,693 & 22.4 & 1,335 & 24.49 & 11,264 & 1.8 & 8.7 & 3.6 & 10.5 & 7.8 & 456.3 \\
\hline D12 & 2.3 & 15.8 & 1,866 & 2,039 & 24.8 & 1,082 & 27.72 & 11,964 & 3.0 & 19.0 & 4.3 & 11.7 & $5,030.1$ & 997.0 \\
\hline D13 & 3.0 & 5.3 & 1,190 & 6,856 & 25.3 & 137 & 24.39 & 6,856 & 2.3 & 90.9 & 6.2 & 3.3 & 59.8 & $1,025.9$ \\
\hline \multicolumn{15}{|c|}{ Dispersion routes } \\
\hline B2 & 8.1 & 2.8 & 669 & 1,241 & 123.2 & 123 & 26.11 & 3,153 & 70.2 & 1.1 & $<\mathrm{dl}$ & $42.8 \times 10^{-3}$ & 1.1 & $<\mathrm{dl}$ \\
\hline B3 & 7.8 & 2.9 & 454 & 3,621 & 33.5 & 124 & 19.23 & 7,958 & 1.5 & 5.6 & 0.8 & 0.3 & 1.7 & 0.5 \\
\hline B4 & 6.9 & 1.4 & 561 & 4,741 & 19.0 & 127 & 24.53 & 7,062 & 1.7 & 2.7 & 0.7 & $9.9 \times 10^{-3}$ & 0.8 & 5.9 \\
\hline B5 & 6.6 & 1.7 & 530 & 6,757 & 19.7 & 145 & 24.23 & 7,239 & 1.8 & 2.5 & 0.4 & $10.1 \times 10^{-3}$ & 1.0 & 9.9 \\
\hline B6 & 5.3 & 0.5 & 644 & 13,500 & 14.7 & 185 & 19.25 & 4,000 & 1.2 & 2.1 & 1.4 & $4.9 \times 10^{-3}$ & 0.7 & 72.4 \\
\hline D1 & 2.5 & 4.5 & 1,593 & 2,471 & 22.5 & 404 & 15.78 & 10,437 & $<\mathrm{dl}$ & 0.9 & 2.4 & 0.1 & $<\mathrm{dl}$ & 38.0 \\
\hline D14 & 4.3 & 2.5 & 3,115 & 554 & 9.5 & 110 & 4.30 & 2,388 & 6.9 & 8.7 & 1.0 & $24.6 \times 10^{-3}$ & 2.9 & 12.2 \\
\hline
\end{tabular}


The analytical data obtained from the sediment samples were classified using correlation analysis and principal component analysis (PCA). The correlation analysis and PCA were undertaken using the Minitab software (version 16). Analyses of correlation coefficients between the physical-chemical parameters of sediments were conducted using the Pearson product-moment correlation coefficient. All results reported are the means of three replicates. For the PCA analysis, only factors with eigenvalues of $>1$ were used. Varimax rotation was applied to aid interpretation of the results.

A multivariate general linear model (GLM) was applied to study the influence on toxicity of the proximity of the source. Considering that the stabilisation approach was carried out by mixing with carbonate, the influence of the carbonate content on the toxicity and trace elements content was evaluated. The statistical calculations were made using SPSS software (version 19).

\section{Results and discussion}

\subsection{Sediment geochemistry}

Sediment samples B1, B7, B8, B11 and B12, located close to the contamination sources, were not mixed with surrounding carbonate materials, and dilution was not evident because the transport process was insignificant. These sediments showed acidic $\mathrm{pH}$ and high EC values (Table 1). The mineralogical composition of these sediments reflected a high percentage of sulphates (gypsum, jarosite and goldichite) together with $\mathrm{Fe}$ oxides and oxyhydroxides (hematite, goethite and akaganeite), quartz, feldspars and clay minerals. Total and soluble metal(loid) contents are high (see Electronic Supplementary Material).

Sampling points $\mathrm{C} 1-\mathrm{C} 7$ are located close to contamination sources, in Cabezo Rajao. Because of the proximity to tailing dumps, transport processes were not important and, similarly to B1, B7, B8, B11 and B12, could act as secondary contamination sources. Sample $\mathrm{C} 1$ had a neutral $\mathrm{pH}$ because, even if strongly affected by mining wastes, the phyllite host rocks would have weakly attenuated the acidity in this sediment. Sample C1 showed a high metal(loid) content, particularly of As (Table 1). Sample C2 also had a neutral pH and, because this sample came from near a stabilised tailing dump, it contained dolomite. Samples C3, C4, C5, C6 and C7 showed similar characteristics to those of the tailing dumps: acidic $\mathrm{pH}$, high metal(loid) content and a mineralogical composition determined by a high sulphate (gypsum and jarosite) percentage, Fe oxides and oxyhydroxides (goethite, hematite and akaganeite), quartz and feldspars.

Samples D2-D13 came from the el Gorguel area and were also strongly affected by old mining exploitation. Two groups 
Fig. 1 Boxplot of total metal(loid) content in Sierra Minera sediment samples

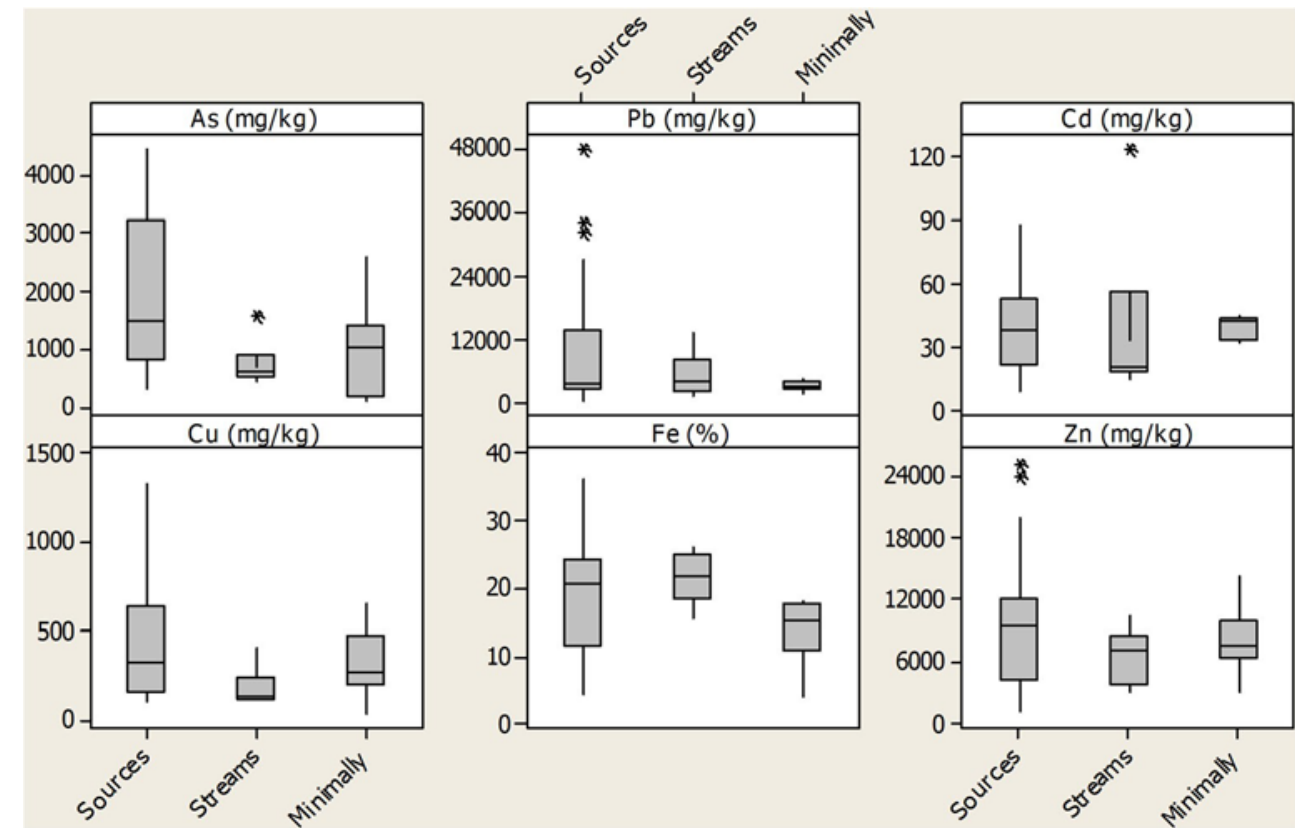

could be established, samples D2-D7 and samples D8D13. The first group was from mining exploitation, which was older than the latter group, in which the materials were much more intensively affected by weathering processes. Sample points D2-D7 are located at the mouth of the Gorguel gully watercourse and are affected by old tailing dumps. The mineralogical composition included jarosite, gypsum, alunite and hydrated sulphates, together with Fe oxides, quartz, clay minerals and feldspars. Sediment samples D8-D13 came from a higher position and were affected by more modern mining exploitation; they had a lower jarosite content (more alteration) and higher gypsum percentage (less alteration) than samples D2-D7. All sediments had an acidic $\mathrm{pH}$, a high metal(loid) concentration and a high EC as a result of the presence of soluble salts (Table 1). The $\mathrm{Zn}$ and Mn contents were higher in samples D8-D13, while the As and $\mathrm{Pb}$ contents were higher in samples D2-D7.

Sediments located in the dispersion routes in Llano del Beal and el Gorguel have been mixed with parent material
Fig. 2 Boxplot of soluble metal(loid) content in Sierra Minera sediment samples

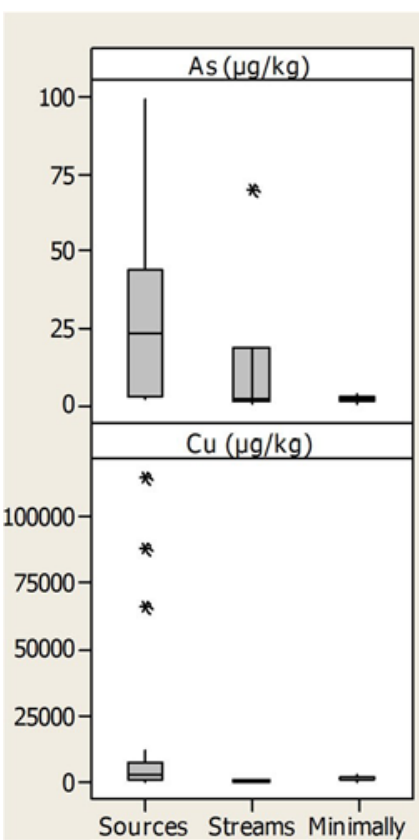

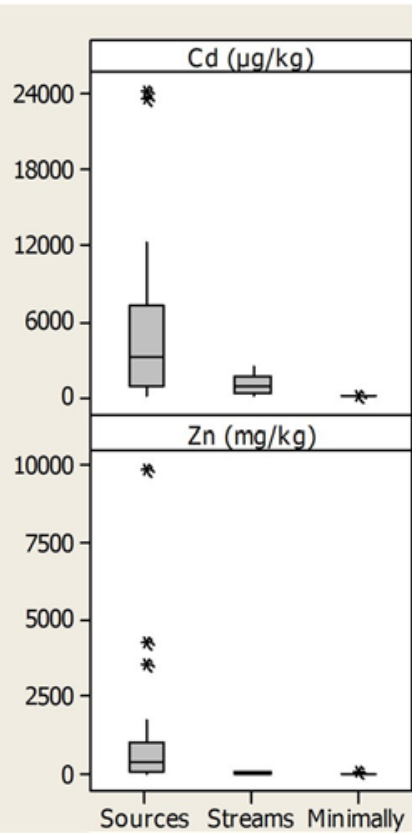


Table2 Analytical parameters of sediment samples before and after the artificial stabilisation

\begin{tabular}{|c|c|c|c|c|c|c|c|c|c|c|c|c|c|c|}
\hline & \multirow[t]{2}{*}{$\mathrm{pH}$} & \multirow[t]{2}{*}{$\mathrm{CE}$} & \multicolumn{6}{|c|}{ Total metal(loid) concentration in sediments } & \multicolumn{6}{|c|}{ Metal(loid) concentration in 1:2 water-sediment extract } \\
\hline & & & As $\left(\mathrm{mg} \mathrm{kg}^{-1}\right)$ & $\mathrm{Pb}\left(\mathrm{mg} \mathrm{kg}^{-1}\right)$ & $\mathrm{Cd}\left(\mathrm{mg} \mathrm{kg}^{-1}\right)$ & $\mathrm{Cu}\left(\mathrm{mg} \mathrm{kg}{ }^{-1}\right)$ & $\mathrm{Fe}(\%)$ & $\mathrm{Zn}\left(\mathrm{mg} \mathrm{kg}{ }^{-1}\right)$ & As $\left(\mu g l^{-1}\right)$ & $\mathrm{Pb}\left(\mathrm{mg} \mathrm{l}^{-1}\right)$ & $\mathrm{Cd}\left(\mathrm{mg} \mathrm{l}^{-1}\right)$ & $\mathrm{Cu}\left(\mathrm{mg} \mathrm{l}^{-1}\right)$ & $\mathrm{Fe}\left(\mathrm{mg} \mathrm{l}^{-1}\right)$ & $\mathrm{Zn}\left(\mathrm{mg} \mathrm{l}^{-1}\right)$ \\
\hline S1 & 5.1 & 18.4 & 503 & 3,106 & 0.4 & 37 & 34.76 & 3,601 & 2.8 & $11.4 \times 10^{-3}$ & $18.2 \times 10^{-3}$ & $7.1 \times 10^{-3}$ & $<\mathrm{dl}$ & 4.0 \\
\hline S2 & 4.1 & 7.1 & 355 & 2,983 & 0.7 & 47 & 30.64 & 3,746 & 19.7 & $4.9 \times 10^{-3}$ & $28.7 \times 10^{-3}$ & $13.8 \times 10^{-3}$ & 2.0 & 230.6 \\
\hline S3 & 4.0 & 5.1 & 334 & 4,738 & 4.8 & 38 & 29.80 & 2,913 & 17.0 & $4.1 \times 10^{-3}$ & $36.9 \times 10^{-3}$ & $18.6 \times 10^{-3}$ & $<\mathrm{dl}$ & 243.8 \\
\hline \multicolumn{15}{|c|}{$10 \%$ filler } \\
\hline S4 & 7.5 & 14.5 & 468 & 2,787 & 0.4 & 35 & 28.84 & 3,055 & 15.9 & $6.0 \times 10^{-3}$ & $1.1 \times 10^{-3}$ & $9.1 \times 10^{-3}$ & $<\mathrm{dl}$ & 0.1 \\
\hline S5 & 7.1 & 7.4 & 230 & 923 & 0.7 & 35 & 27.40 & 2,894 & 7.7 & $7.9 \times 10^{-3}$ & $1.3 \times 10^{-3}$ & $8.1 \times 10^{-3}$ & $<\mathrm{dl}$ & 0.2 \\
\hline S6 & 6.8 & 5.7 & 300 & 1,562 & 3.2 & 27 & 27.00 & 4,179 & 5.1 & $3.0 \times 10^{-3}$ & $5.9 \times 10^{-3}$ & $70.2 \times 10^{-3}$ & $<\mathrm{dl}$ & 0.4 \\
\hline \multicolumn{15}{|c|}{$20 \%$ filler } \\
\hline S7 & 7.7 & 13.5 & 416 & 2,396 & 0.4 & 31 & 29.18 & 2,967 & 18.4 & $6.2 \times 10^{-3}$ & $0.7 \times 10^{-3}$ & $10.1 \times 10^{-3}$ & $<\mathrm{dl}$ & 0.1 \\
\hline S8 & 7.4 & 5.2 & 180 & 240 & 0.3 & 29 & 21.95 & 3,226 & 10.8 & $2.0 \times 10^{-3}$ & $0.4 \times 10^{-3}$ & $24.5 \times 10^{-3}$ & $<\mathrm{dl}$ & 0.1 \\
\hline S9 & 7.3 & 3.7 & 283 & 181 & 2.7 & 27 & 21.20 & 3,725 & 8.5 & $1.7 \times 10^{-3}$ & $0.6 \times 10^{-3}$ & $11.8 \times 10^{-3}$ & $<\mathrm{dl}$ & 0.1 \\
\hline \multicolumn{15}{|c|}{$30 \%$ filler } \\
\hline S10 & 7.8 & 12.5 & 364 & 2,034 & 0.5 & 29 & 25.69 & 2,512 & 19.3 & $5.8 \times 10^{-3}$ & $0.7 \times 10^{-3}$ & $12.1 \times 10^{-3}$ & $<\mathrm{dl}$ & 0.1 \\
\hline S11 & 7.5 & 7.1 & 97 & 217 & 0.4 & 33 & 34.15 & 2,170 & 10.6 & $3.0 \times 10^{-3}$ & $0.5 \times 10^{-3}$ & $22.3 \times 10^{-3}$ & $<\mathrm{dl}$ & 0.4 \\
\hline S12 & 7.5 & 3.1 & 240 & 114 & 2.9 & 70 & 18.50 & 4,080 & 14.5 & $2.6 \times 10^{-3}$ & $0.7 \times 10^{-3}$ & $13.1 \times 10^{-3}$ & $<\mathrm{dl}$ & 0.1 \\
\hline
\end{tabular}

$<$ dl below the detection limit 
during transport processes. These sediments had a neutral or slightly acidic $\mathrm{pH}$, higher than the values determined in sediments located close to the contamination sources. In samples $\mathrm{B} 2$ and B3, the mineralogical composition reflected the presence of calcite, confirming the neutralisation and natural attenuation processes they had undergone. In the other sediment samples, the attenuation resulted from mixing with phyllites (host rock). The mineralogical composition of sediment samples D14 and D15 confirmed the existence of minerals from host rocks and the absence of weathering products. The presence of carbonate minerals in sufficient quantity to neutralise the acidity produced by the dissolution of sulphides prevented the generation of acidic waters. However, in places without carbonates, pH buffering had been carried out by aluminosilicates. These minerals are dissolved more slowly than carbonates and their neutralisation capacity is much lower (Asta 2011). If carbonated minerals have been completely dissolved and the buffering potential of aluminosilicate minerals is not sufficiently effective, the $\mathrm{pH}$ value could decrease and aluminium hydroxides or sulphates, such as alunite or gibbsite, would precipitate (sediment sample D1). Total and soluble metal(loid) concentrations were lower than in sediments affected by primary contamination, but were still high.

In sediments located further from the contamination sources and minimally affected by mining activities, the neutralisation process would have taken place when mining materials were in contact with minerals that are able to generate alkalinity, particularly with carbonates. The neutralisation process unchains a series of reactions of trace element mitigation, since many of the elements tend to precipitate when the $\mathrm{pH}$ increases (Lottermoser 2007). The mineralogical composition of these sediments included calcite and dolomite. Moreover, jarosite was present in low percentages while alunite and soluble sulphates were not present because they originate in the weathering processes that occur in tailing dumps and in sediments located close to the sources. However, due to the dilution effect caused by the presence in the sediments of large quantities of materials not influenced by mining activities, the concentrations of these minerals were below the limit of XRD detection and they could not be identified. The metal(loid) content in these sediments was lower than that determined in sediments described above (Table 1). Figures 1 and 2 show a boxplot for the total and soluble contents of selected sediments and demonstrate that the sediments collected close to contamination sources have higher amounts of metal(loid)s than those collected in the gully watercourses as a result of transport processes or those located further from the tailing dumps.

Sediment samples selected for the study of artificial stabilisation showed little differences in $\mathrm{pH}$, which ranged from 4.0 to 5.1, indicating acidic conditions (Table 2). Electrical conductivity values ranged from 5.1 to $18.4 \mathrm{dS} \mathrm{m}^{-1}$. The concentrations of metal(loid)s found in the sediments seem to be strongly influenced by mining activities (Table 2). When polluted sediment samples were mixed with filler limestone (10-30\%), the metal(loid) concentrations decreased with increasing carbonate content. More particularly, the soluble trace element content diminished strongly. This immobilisation approach showed that if polluted sediment samples are mixed with filler limestone in a proportion that varies from 20 to $30 \%$, stabilised sediments behave similarly to those sediments
Fig. 3 Boxplot of total metal(loid) content in sediment samples before and after the artificial stabilisation

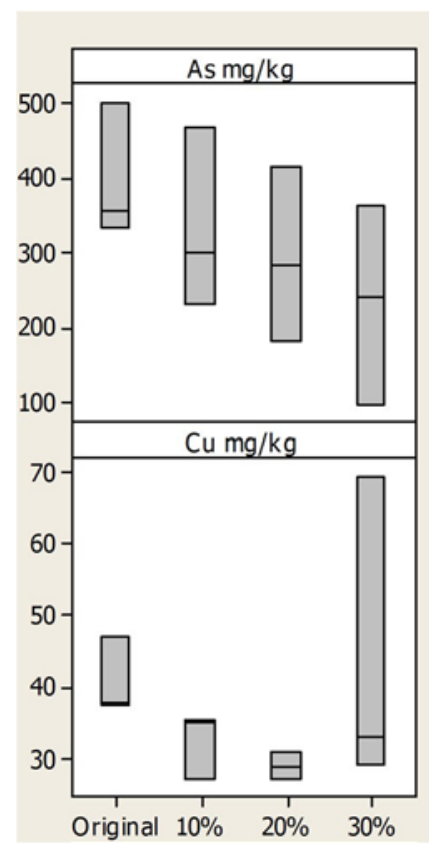

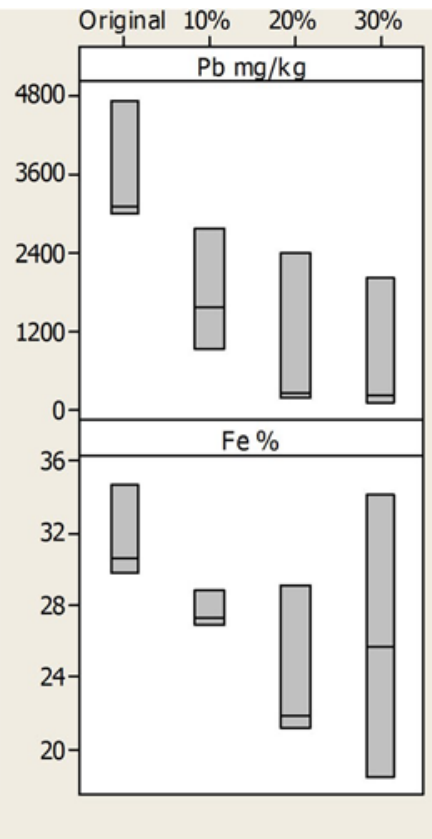

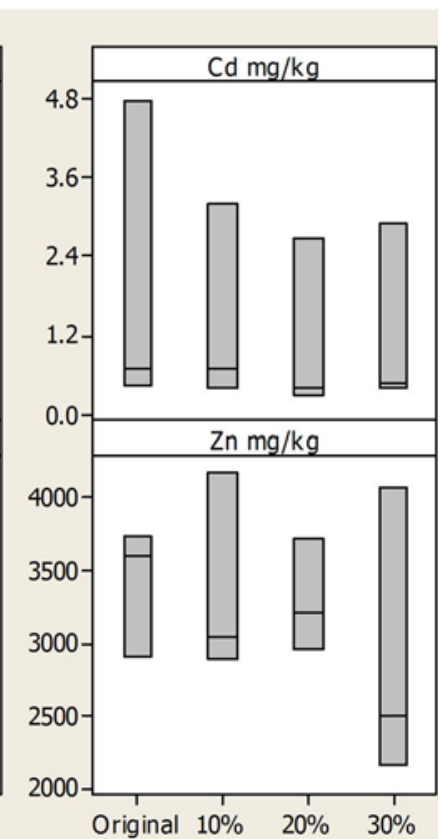


Fig. 4 Boxplot of soluble metal(loid) content in sediment samples before and after the artificial stabilisation
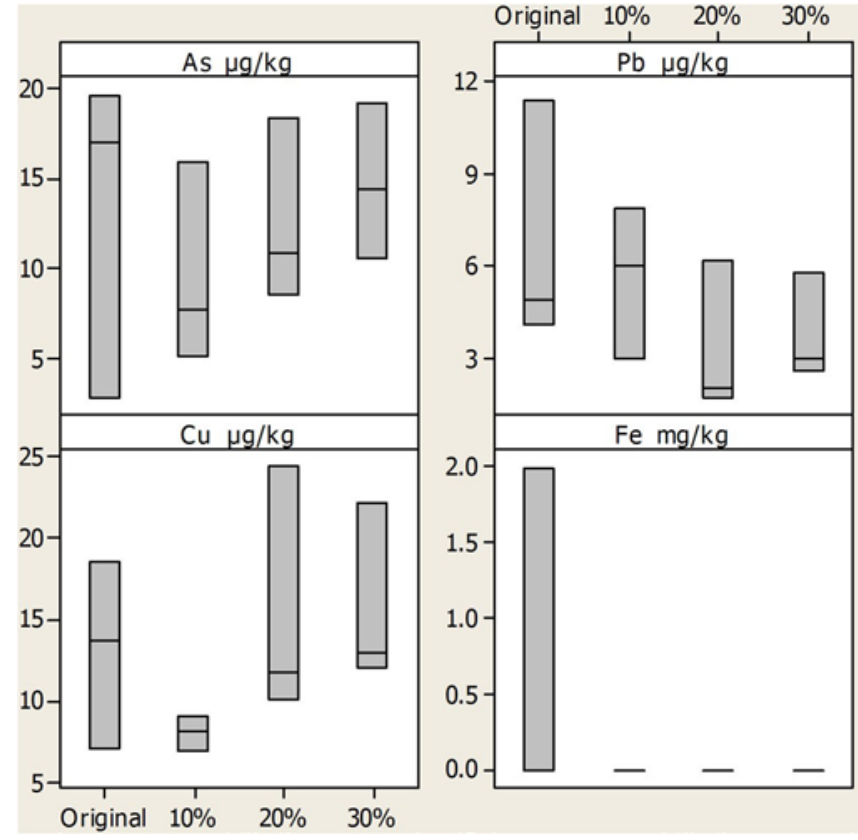

where natural attenuation has taken place as a result of mixing with carbonate materials. Figures 3 and 4 show a boxplot for the total and soluble metal(loid) contents in sediments selected for the stabilisation approach, before and after the treatment. The results obtained are similar to those obtained for the Sierra Minera samples, in that the metal(loid) content diminishes with increasing filler percentage. Stabilisation simulation is therefore similar to the natural attenuation process.

In the PCA, five eigenvalues exceeding unity were found. The first component explains $30.7 \%$ of the total variance and loads soluble $\mathrm{As}, \mathrm{Pb}$ and $\mathrm{Cu}$ together with jarosite and soluble sulphates. The second component, dominated by calcite, dolomite and $\mathrm{pH}$ accounts for $15.5 \%$ of the total variance. The third component is loaded by soluble $\mathrm{Cd}$ and $\mathrm{Zn}$, accounting for $12.7 \%$ of the total variance. The fourth component is dominated by gypsum and akaganeite, accounting for $10.4 \%$ of the total variance, and the fifth component loads electrical conductivity and soluble Fe content, accounting $7.9 \%$ of the total variance. The PCA scores according to the first and second principal components (Fig. 5) show that the sediment samples collected furthest from the contamination sources had neutral or basic $\mathrm{pH}$ and high carbonate percentage.

On the other hand, samples with a high soluble metal(loid) content, containing sulphates and with acidic $\mathrm{pH}$, correspond to sediments from close to contamination sources. This means

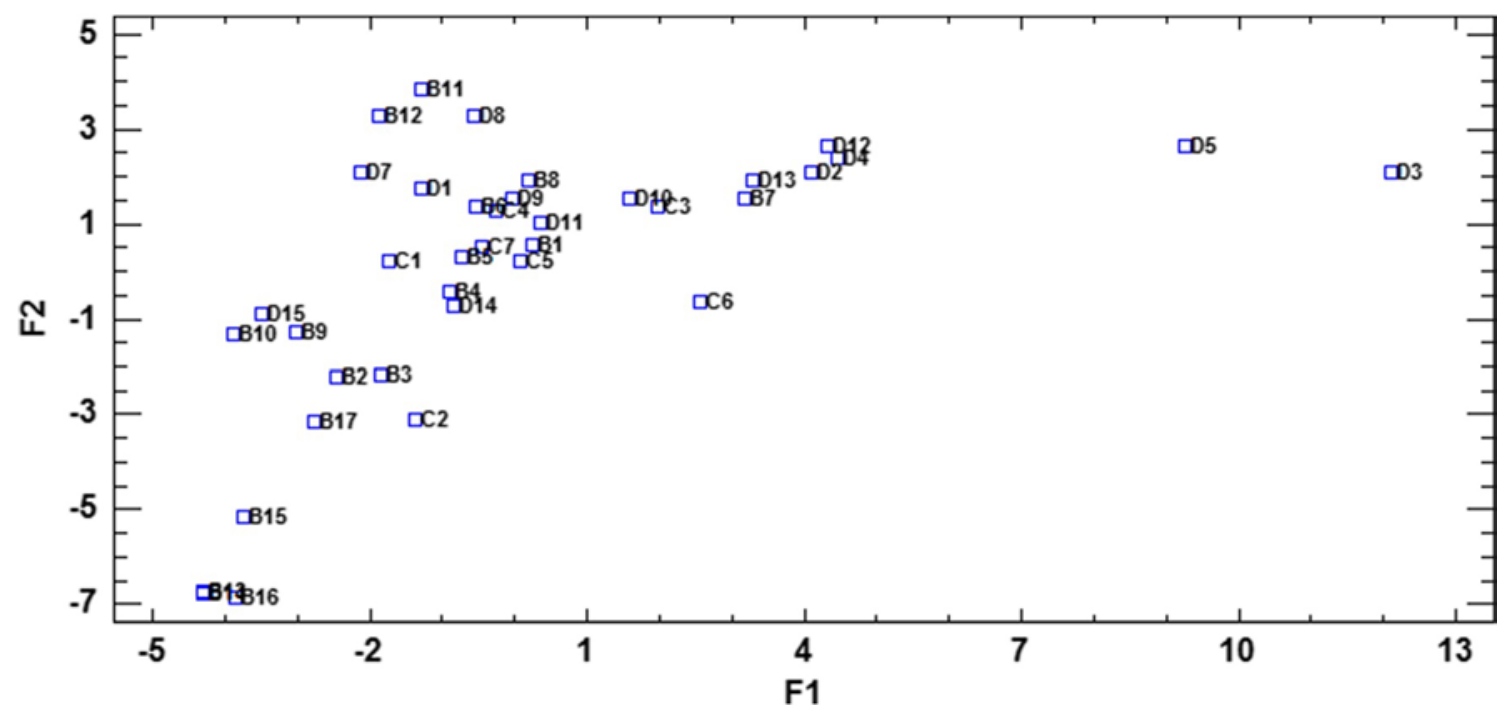

Fig. 5 Principal components analysis (PCA) score plot 
Table3 Germination inhibition index (\%) in sediment samples

\begin{tabular}{llll}
\hline Control & S.saccharatum & L.sativum & $\begin{array}{l}\text { S.alba } \\
88\end{array}$ \\
& 92 & 96 & 88 \\
\hline
\end{tabular}

\section{Contamination sources}

B1 53

B7 11

B8 69

B11 54

B12 67

C1 84

C2 57

C3 0

C4 0

C5 86

C6 69

C7 47

D2 29

D3 0

D4 0

D5 0

D6 11

D7 48

D8 50

D9 0

D10 0

D11 0

D12 0

D13 0

Dispersion routes

B2 40

B3 10

B4 99

B5 97

B6 85

D1 50

D14 90

D15 18

Minimally affected

B9 82

B10 62

B13 82

B14 86

B15 21

B16 86

B17 100

Artificial stabilisation

Control 99

S1 0

S2 12

S3
80

15

50

80

90

79

72

0

0

8

59

54

0

0

0

0

0

98

98

0

0

0

79

0

128

131

45

10

85

110

95

99

107

111

79

72

88

110

0

14

8
Table3 (continued)

\begin{tabular}{clll}
\hline Control & $\begin{array}{l}\text { S.saccharatum } \\
92\end{array}$ & $\begin{array}{l}\text { L.sativum } \\
96\end{array}$ & $\begin{array}{l}\text { S.alba } \\
88\end{array}$ \\
\hline $10 \%$ filler & & & \\
S4 & 0 & 0 & 0 \\
S5 & 20 & 15 & 7 \\
S6 & 33 & 46 & 13 \\
$20 \%$ filler & & & \\
S7 & 0 & 0 & 0 \\
S8 & 35 & 40 & 31 \\
S9 & 77 & 63 & 40 \\
$30 \%$ filler & & & \\
S10 & 0 & 0 & 76 \\
S11 & 78 & 80 & 94 \\
S12 & 97 & 95 & \\
\hline
\end{tabular}

that the attenuation process (in the form of mixing wit carbonate materials) took place during transport.

\subsection{Phytotoxicity test}

The results obtained in the bioassay and with the toxic ity index are presented in Table 3. Figure 6 shows a boxplot $\mathrm{f}$ or the toxicity index in the sediment samples. Of the vario us toxicity indices which are based on germination and the ear ly growth of higher plants, the germination index (GI) a $\mathrm{p}^{-}$ pears to be a good method for assessing the toxicity of sediments (Czerniawska-Kusza and Kusza 2011). In this study, two species of dicotyledonous plants (S. alba and L. sativum) and one species of monocotyledonous plants (S. saccharatum) presented different reactions to the contaminants contained in these sediments. The GI value in samples collected from close to the contamination sources was zero in C3, C4, D3, D4, D5 and D9 to D13 because no seeds germinated. The GI for the other sediments strongly affected by mining activities ranged from 11 to $86 \%$ for $S$. saccharatum, from 8 to $98 \%$ for L. sativum and from 9 to $97 \%$ for S. alba. When sediments collected from the dispersion routes were evaluated, the GI index was higher than for the above samples, except in the case of B3, which the GI values for all three species suggested was a highly toxic sediment sample. The GI ranged from 40 to $99 \%$ for $S$. saccharatum, while the values for B4, B5 and D14 were not statistically different from the control (GI 90-110\%). The GI for L. sativum ranged from 10 to $131 \%$, and inhibition was quantified in samples B2, B3, B6, D1 and D14. Samples B4, B5 and D15 had GI values of $>110 \%$, reflecting stimulated growth.

In the sediment samples minimally affected by mining activities, where mixing with carbonates attenuated 
Fig. 6 Boxplot of the germination index $(\mathrm{GI})$

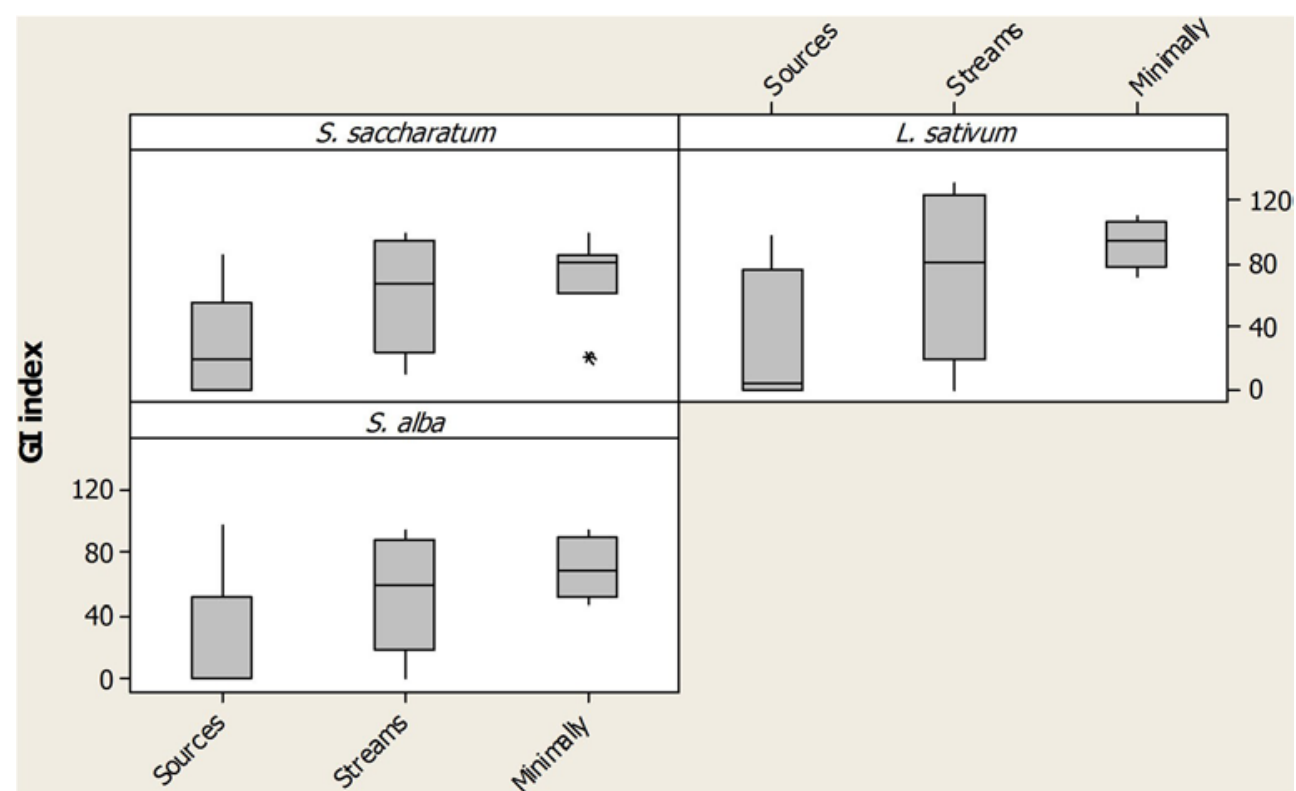

metal(loid) contamination, the GI values are similar to those obtained for the control sample (unaffected by mining activities). The GI was within the range $21-100 \%$ for S. saccharatum, $72-111 \%$ for $L$. sativum and $47-94 \%$ for S. alba. In almost all samples, no effect or stimulation was determined, suggesting that toxicity was lower than in the other samples. Figure 6 confirmed that toxicity decreased with distance from the source and then with mixing with surrounding materials.

When samples selected for the artificial stabilisation were evaluated before treatment; GI values were lower than $15 \%$ for all sediments, being zero for all three species in S1 and for S. alba in S2 and S3. When these sediments were mixed with limestone filler, the stabilised S1 samples (S4, S7 and S10) still showed very high toxicity (GI=0), suggesting that $30 \%$ limestone filler is not sufficient to diminish the toxicity level. However, for S2 samples mixed with 10 and $20 \%$ limestone filler, the toxicity decreased for all three species, although inhibition was still evident (GI $<90 \%$ ). When a limestone percentage of $30 \%$ was used, the GI values were $78 \%$ for S. saccharatum, $80 \%$ for L. sativum and $76 \%$ for S. alba. In the case of stabilised samples of the S3 sediment, mixing with $30 \%$ of limestone strongly decreased toxicity, the GI taking values from 90 to $110 \%$ suggesting that there was no effect on the plants. When 10 and $20 \%$ of limestone filler were added, the toxicity also decreased, but inhibition was still evident (GI $<90 \%$ ).

\subsection{Correlation analysis}

An analysis of the correlation between the concentration of metal(loid)s and the results of the toxicity was carried out
(Table 4). Positive values of the correlation coefficients indicate a connection between the metal concentration in sediments and toxicity for plants, whereas negative values mean that an increased metal concentration does not increase sample toxicity. Tests showed a positive correlation between the total concentrations of $\mathrm{As}$ and $\mathrm{Cu}$ and GI in $L$. sativum and S. alba. The total concentration of the metals in the sediments did not influence the increase in germination inhibition in $S$. saccharatum. In terms of the relationship between GI and the soluble metal(loid) content, $\mathrm{Pb}, \mathrm{Cd}, \mathrm{Cu}$ and $\mathrm{Zn}$ were negatively correlated with GI for the three species. In addition, the soluble Fe content was negatively correlated with the GI of $S$. saccharatum.

A positive correlation was found between $\mathrm{pH}$ and GI for the three species, suggesting that acidity increases plant toxicity. In addition, the toxicity index was negatively correlated with electrical conductivity.

Table4 Correlation analysis results

\begin{tabular}{|c|c|c|c|}
\hline & GI S. saccharatum & GI L. sativum & GI S. alba \\
\hline $\mathrm{pH}$ & 0.66 & 0.72 & 0.71 \\
\hline EC & -0.58 & -0.56 & -0.57 \\
\hline \multirow[t]{2}{*}{ Total content } & & As $(-0.47)$ & As $(-0.41)$ \\
\hline & & $\mathrm{Cu}(-0.45)$ & $\mathrm{Cu}(-0.41)$ \\
\hline \multirow[t]{5}{*}{ Soluble content } & $\mathrm{Pb}(-0.42)$ & $\mathrm{Pb}(-0.36)$ & $\mathrm{Pb}(-0.45)$ \\
\hline & Cd $(-0.54)$ & Cd $(-0.55)$ & Cd $(-0.56)$ \\
\hline & $\mathrm{Cu}(-0.51)$ & $\mathrm{Cu}(-0.48)$ & $\mathrm{Cu}(-0.47)$ \\
\hline & Zn $(-0.46)$ & Zn $(-0.44)$ & Zn $(-0.43)$ \\
\hline & $\mathrm{Fe}(-0.42)$ & & \\
\hline
\end{tabular}


Table5 General linear model (GLM) showing the effects of source distance and carbonate content in trace elements content and phytotoxicity indices

\begin{tabular}{|c|c|c|c|c|}
\hline & Type III sum of squares & Mean squares & $F$ value & $p$ value \\
\hline \multicolumn{5}{|l|}{ Source distance } \\
\hline $\mathrm{pH}$ & 83.66 & 41.83 & 16.06 & 0.000 \\
\hline Soluble As (mg l${ }^{-1}$ ) & $55.30 \times 10^{2}$ & $27.65 \times 10^{2}$ & 4.71 & 0.015 \\
\hline Soluble Cd (mg l$\left.{ }^{-1}\right)$ & $2.61 \times 10^{8}$ & $1.31 \times 10^{8}$ & 4.63 & 0.016 \\
\hline Soluble Cu (mg l-1) & $1.78 \times 10^{9}$ & $8.88 \times 10^{8}$ & 1.52 & 0.033 \\
\hline GI S. saccharatum (\%) & $12.98 \times 10^{3}$ & $64.90 \times 10^{2}$ & 6.45 & 0.004 \\
\hline GI L. sativum (\%) & $24.47 \times 10^{3}$ & $12.24 \times 10^{3}$ & 8.10 & 0.001 \\
\hline GI S. alba (\%) & $14.21 \times 10^{3}$ & $71.04 \times 10^{2}$ & 7.39 & 0.002 \\
\hline Jarosite (\%) & $13.00 \times 10^{2}$ & $6.50 \times 10^{2}$ & 8.68 & 0.001 \\
\hline Carbonate (\%) & $20.20 \times 10^{2}$ & $10.10 \times 10^{2}$ & 47.38 & 0.000 \\
\hline \multicolumn{5}{|l|}{ Carbonate content } \\
\hline $\mathrm{pH}$ & 92.02 & 46.01 & 17.54 & 0.000 \\
\hline Soluble As (mg l-1) & $23.77 \times 10^{2}$ & $11.89 \times 10^{2}$ & 2.25 & 0.016 \\
\hline Soluble Cd (mg l'-1) & $2.38 \times 10^{8}$ & $1.19 \times 10^{9}$ & 4.90 & 0.012 \\
\hline Soluble Cu (mg l$\left.{ }^{-1}\right)$ & $1.29 \times 10^{9}$ & $6.44 \times 10^{9}$ & 1.38 & 0.040 \\
\hline Iron oxides (\%) & $5.80 \times 10^{2}$ & $2.90 \times 10^{2}$ & 8.91 & 0.001 \\
\hline Gypsum (\%) & $2.76 \times 10^{2}$ & $1.38 \times 10^{2}$ & 4.07 & 0.023 \\
\hline Total As (mg kg-1) & $13.37 \times 10^{6}$ & $66.83 \times 10^{5}$ & 5.72 & 0.006 \\
\hline Total Pb (mg kg-1) & $5.35 \times 10^{9}$ & $2.68 \times 10^{9}$ & 3.14 & 0.042 \\
\hline GI S. saccharatum (\%) & $21.63 \times 10^{2}$ & $10.81 \times 10^{2}$ & 0.83 & 0.041 \\
\hline GI L. sativum (\%) & $45.48 \times 10^{2}$ & $22.74 \times 10^{2}$ & 1.19 & 0.012 \\
\hline GI S. alba (\%) & $47.03 \times 10^{2}$ & $23.51 \times 10^{2}$ & 1.93 & 0.056 \\
\hline
\end{tabular}

The multivariate GLM was applied to determine the effect of source proximity on the toxicity results and the trace element contents. Three groups were established: samples located close to the source, samples located along the dispersion routes and samples located far from the source. The results suggested that the source proximity influenced the toxicity indices for all selected species ( $p$ value lower than the significance level) and the soluble As, Cd and Cu content. Moreover, the jarosite and carbonate content varied between the different groups (Table 5).

Since the stabilisation approach involved mixing polluted sediments with carbonates, the influence of this variable on the toxicity and trace element contents was also assessed. Three groups were established: samples with a carbonate percent $<10 \%$, samples with a carbonate ranging from 10 to $20 \%$ and samples with a content $>20 \%$. The results of this analysis (Table 5) suggest that the carbonate content influences the toxicity results (represented as the toxicity indices) and also the soluble As, $\mathrm{Cd}$ and $\mathrm{Cu}$ content. In addition, the total $\mathrm{As}$ and $\mathrm{Pb}$ concentrations and the gypsum and Fe contents varied with the carbonate percent. Taking into account that the phytotoxicity results depend on the influence of the source and the carbonate percent, the proposed bioassay could be used as a tool for trace element toxicity evaluation. In addition, the GLM results showed that the proposed treatment could be used to remediate soils contaminated by trace elements and could even be applied in areas affected by mining activities, because the toxicological effect in the tested organisms was reduced significantly.

\section{Conclusions}

This study showed that mineral buffering and dilution are the main processes in the geochemical control of AMD in the Sierra Minera of Cartagena-La Unión. Mixing with carbonate materials attenuated acidity and metal(loid) contamination. Simulation of this attenuation in three sediments affected by mining activities and mixed with different percentages of limestone filler showed that the addition of this amendment represents a useful and low-impact strategy to reduce the soluble fractions of $\mathrm{As}, \mathrm{Cd}, \mathrm{Cu}, \mathrm{Fe}, \mathrm{Pb}$ and $\mathrm{Zn}$. The toxicity results showed that it is possible with selected amendments to immobilise heavy metals and hence to reduce the toxicity of sediments. The addition of limestone filler significantly reduced the toxicological effect on the tested organisms. The applied bioassay is a good tool for the screening of metal(loid) contamination in areas affected by mining activities and provides information about natural and simulated attenuation processes. 


\section{References}

Asta MP (2011) Procesos geoquímicos en aguas ácidas por meteorización de sulfuros. Bol Geol Min 122:259-272

Asta MP, Ayora C, Acero P, Cama J (2010) Field rates for natural attenuation of arsenic in Tinto Santa Rosa acid mine drainage (SW Spain). J Hazard Mater 177:1102-1111

Bagur-González MG, Estepa-Molina C, Martín-Peinado F, MoralesRuano S (2011) Toxicity assessment using Lactuca sativa L. bioassay of the metal(loid)s $\mathrm{As}, \mathrm{Cu}, \mathrm{Mn}, \mathrm{Pb}$ and $\mathrm{Zn}$ in soluble-in-water saturated soil extracts from an abandoned mining site. J Soils Sediments 11:281-289

Bakopoulou S, Emmanouil C, Kungolos A (2011) Assessment of wastewater effluent quality in Thessaly region, Greece, for determining its irrigation reuse potential. Ecotoxicol Environ Saf 74:188-194

Baran A, Tarnawski M (2013) Phytotoxkit/Phytotestkit and Microtox as tools for toxicity assessment of sediments. Ecotoxicol Environ Saf 98:19-27

Berger AC, Bethke CM, Krumhansl JL (2000) A process model of natural attenuation in drainage from a historic mining district. Appl Geochem 15:655-666

Chapman BM, Jones DR, Jung RF (1983) Processes controlling metal ion attenuation in acid mine drainage streams. Geochim Cosmochim Acta 47:1957-1973

Czerniawska-Kusza I, Kusza G (2011) The potential of the Phytotoxkit microbiotest for hazard evaluation of sediments in eutrophic freshwater ecosystems. Environ Monit Assess 179:113-121

Garau G, Castaldi P, Santona L, Deiana P, Melis P (2007) Influence of red mud, zeolite and lime on heavy metal immobilization, culturable heterotrophic microbial populations and enzyme activities in a contaminated soil. Geoderma 142:47-57

García-Lorenzo ML, Martínez-Sánchez MJ, Pérez-Sirvent C, Molina J (2009) Ecotoxicological evaluation for the screening of areas polluted by mining activities. Ecotoxicology 18:1077-1086

García-Lorenzo ML, Pérez-Sirvent C, Martínez-Sánchez MJ, MolinaRuiz J (2012) Trace elements contamination in an abandoned mining site in a semiarid zone. J Geochem Explor 113:23-35

Gómez-Ros JM, García G, Peñas JM (2013) Assessment of restoration success of former metal mining areas after 30 years in a highly polluted Mediterranean mining area: Cartagena-La Unión. Ecol Eng 57:393-402

Kopec M, Gondek K, Baran A (2013) Assessment of respiration activity and ecotoxicity of compost containing biopolymers. Ecotoxicol Environ Saf 89:137-142

Kosobucki P, Kruk M, Buszewski B (2008) Immobilization of selected heavy metals in sewage sludge by natural zeolites. Bioresour Technol 99:5972-5976

Leitgib L, Kálmán J, Gruiz K (2007) Comparison of bioassays by testing whole soil and their water extract from contaminated sites. Chemosphere 66:428-434

Liu Y, Naidu R, Ming H (2011) Red mud as an amendment for pollutants in solid and liquid phases. Geoderma 163:1-12

López-Roldán R, Kazlauskaite L, Ribo J, Riva MC, González S, Cortina JL (2012) Evaluation of an automated luminescent bacteria assay for in situ aquatic toxicity determination. Sci Total Environ 440:307-313
Lottermoser BG (2007) Mine wastes: characterization, treatment and environmental impacts. Springer, Berlin

Madrid F, Florido MC (2010) Effects of the presence of a composted biosolid on the metal immobilizing action of an urban soil. J Hazard Mater 176:792-798

Martin JD (2004) Using XPowder: a software package for powder X-ray diffraction analysis. www.xpowder.com D.L. GR 1001/04. ISBN 84-609-1497-6. $105 \mathrm{p}$

Martínez-Sánchez MJ, Navarro MC, Pérez-Sirvent C, Marimón J, Vidal J, García-Lorenzo ML, Bech J (2008) Assessment of the mobility of metals in a mining-impacted coastal area (Spain, Western Mediterranean). J Geochem Explor 86:171-182

Mignardi S, Corami A, Ferrini V (2012) Evaluation of the effectiveness of phosphate treatment for the remediation of mine waste soils contaminated with $\mathrm{Cd}, \mathrm{Cu}, \mathrm{Pb}$ and $\mathrm{Zn}$. Chemosphere 86:354-360. doi:10.1016/j.chemosphere.2011.09.050

Nordstrom DK (1982) The effect of sulfate on aluminium concentrations in natural waters: some stability relations in the system $\mathrm{Al}_{2} \mathrm{O}_{3}-\mathrm{SO}_{3}$ $\mathrm{H}_{2} \mathrm{O}$ at 298K. Geochim Cosmochim Acta 46:681-692

OECD (1984) Guideline of the OECD for testing chemical productsterrestrial plants. Growth Test Method 208, Paris, France

Oen IS, Fernandez JC, Manteca JI (1975) The lead-zinc and associated ores of La Union, Sierra de Cartagena, Spain. Econ Geol 70: 1259-1278

Oleszczuk P, Malara A, Jósko I, Lesiuk A (2012) The phytotoxicity changes of sewage sludge-amended soils. Water Air Soil Pollut 223:4937-4948

Ovejero G, Jacquin JP, Servajean G (1976) Les minéralisations et leur contexte géologique dans la Sierra de Cartagena (sud-est de léspagne). Bull Soc Geol Fr 7(t. XVIII, no. 3):619-633

Pérez-Sirvent C, García-Lorenzo ML, Martínez-Sánchez MJ, Navarro MC, Marimón J, Bech J (2007) Metal-contaminated soil remediation by using sludges of the marble industry: toxicological evaluation. Environ Int 33:502-504

Pérez-Sirvent C, García-Lorenzo ML, Martínez-Sánchez MJ, MolinaRuiz J, Marimón J, Navarro MC (2011) Use of marble cutting sludges for remediating soils and sediments contaminated by heavy metals. Environ Progr Sustain Energ 30:533-539

Phytotoxkit (2004) Seed germination and early growth microbiotest with higher plants. Standard operation procedure. Microbiotest, Nazareth

Plaza G, Nalecz-Jawexki G, Ulfig K, Brigmon RL (2005) The application of bioassays as indicators of petroleum-contaminated soil remediation. Chemosphere 59:289-296

Sarmiento AM, Olías M, Nieto JM, Canóvas CR, Delgado J (2009) Natural attenuation processes in two water reservoirs receiving acid mine drainage. Sci Total Environ 407:2051-2062

Scanferla P, Ferrari G, Pellay R, Volpi Ghirardini A, Zanetto G, Libralato G (2009) An innovative stabilisation/solidification treatment for contaminated soil remediation: demonstration project results. J Soils Sediments 9:229-236

Shi W, Shao H, Li H, Shao M, Du S (2009) Progress in the remediation of hazardous heavy metal-polluted soils by natural zeolite. J Hazard Mater 170:1-6

Wadhia K, Thompson KC (2007) Low-cost ecotoxicity testing of environmental samples using microbiotests for potential implementation of water framework directive. Trends Anal Chem 26:307-322 